\title{
Excessive Prenatal Supplementation of lodine and Fetal Goiter: Report of Two Cases Using Three-dimensional Ultrasound and Magnetic Resonance Imaging
}

\section{Suplementação pré-natal excessiva de iodo e bócio fetal: Relato de dois casos utilizando ultrassonografia tridimensional e ressonância magnética}

\author{
Pedro Castro ${ }^{1,2}$ Heron Werner ${ }^{1(1)}$ Paulo Roberto Silva Marinho ${ }^{3(0)}$ Ana Paula Matos ${ }^{10}$ \\ Pedro Pires ${ }^{4}$ Edward Araujo Júnior ${ }^{5,60}$
}

${ }^{1}$ Department of Fetal Medicine, Clínica de Diagnóstico por Imagem,

Address for correspondence Edward Araujo Júnior, PhD, Rua Belchior Rio de Janeiro, RJ, Brazil

2 Department of Radiology, Universidade Federal do Rio de Janeiro, de Azevedo, 156 apto. 111 Torre Vitoria, São Paulo-SP, Brazil

Rio de Janeiro, RJ, Brazi

${ }^{3}$ Department of Obstetrics and Gynecology, Universidade Federal do (e-mail: araujojred@terra.com.br).

Estado do Rio de Janeiro, Rio de Janeiro, RJ, Brazil

${ }^{4}$ Department of Obstetrics and Gynecology, Universidade de

Pernambuco, Recife, PE, Brazil

${ }^{5}$ Department of Obstetrics, Escola Paulista de Medicina, Universidade

Federal de São Paulo, São Paulo, SP, Brazil

6 Medical course, Universidade Municipal de São Caetano do Sul,

São Paulo, SP, Brazil

Rev Bras Ginecol Obstet 2021;43(4):317-322.

\section{Abstract \\ Keywords \\ - fetal goiter \\ - prenatal care \\ - iodine supplementation \\ - three-dimensional ultrasound \\ - magnetic resonance imaging}

\section{Resumo}

Fetal thyroid complications in pregnancy are uncommon, and are commonly related to the passage of substances through the placenta. The excessive iodine intake during the pregnancy is a well-known mechanism of fetal thyroid enlargement or goiter, and invasive procedures have been proposed for the treatment of fetal thyroid pathologies. In the present report, we demonstrate two cases from different centers of prenatal diagnosis of fetal thyroid enlargement and/or goiter in three fetuses (one pair of twins, wherein both fetuses were affected, and one singleton pregnancy). The anamnesis revealed the ingestion of iodine by the patients, prescribed from inadequate vitamin supplementation. In both cases, the cessation of iodine supplement intake resulted in a marked reduction of the volume of the fetal thyroid glands, demonstrating that conservative treatment may be an option in those cases. Also, clinicians must be aware that patients may be exposed to harmful dosages or substances during pregnancy.

As complicações fetais da tireoide na gravidez são incomuns e são comumente relacionadas à passagem de substâncias pela placenta. A ingestão excessiva de iodo received

February 18, 2020

accepted

February 2, 2021
DOI https://doi.org/

10.1055/s-0041-1729143. ISSN $0100-7203$. (c) 2021. Federação Brasileira de Ginecologia e Obstetrícia. All rights reserved.

This is an open access article published by Thieme under the terms of the Creative Commons Attribution License, permitting unrestricted use, distribution, and reproduction so long as the original work is properly cited. (https://creativecommons.org/licenses/by/4.0/)

Thieme Revinter Publicações Ltda., Rua do Matoso 170, Rio de Janeiro, RJ, CEP 20270-135, Brazil 


\author{
Palavras-chave \\ - bócio fetal \\ - atenção pré-natal \\ - suplementação de \\ iodo \\ - ultrassonografia \\ tridimensional \\ - ressonância \\ magnética
}

\begin{abstract}
durante a gravidez é um mecanismo bem conhecido de aumento da tireoide ou bócio fetal, e procedimentos invasivos foram propostos para o tratamento de patologias da tireoide fetal. No presente relato de caso, demonstramos dois casos de diferentes centros de diagnóstico pré-natal de aumento da tireoide fetal e/ou bócio em três fetos (um par de gêmeos, em que ambos os fetos foram afetados, e uma gravidez única). A anamnese revelou a ingestão de iodo pelos pacientes prescrita por suplementação inadequada de vitaminas. Nos dois casos, a interrupção da ingestão de suplemento de iodo resultou em uma redução acentuada do volume das glândulas tireoides fetais, demonstrando que o tratamento conservador pode ser uma opção nestes casos. Além disso, os médicos devem estar cientes de que as pacientes podem ser expostas a doses ou substâncias nocivas durante a gravidez.
\end{abstract}

\section{Introduction}

The thyroid gland is essential for the neurodevelopment in the embryo and in the fetus; fetal thyroid pathologies can cause perinatal complications ranging from preterm delivery and airway obstruction to severe psychomotor impairment in childhood. ${ }^{1}$ The incidence of fetal thyroid complications during pregnancy is of $\sim 1$ per 4,000 live births, and it is usually related to the passage through the placenta of substances ingested by the mother during pregnancy or by antibodies acting on the fetal thyroid tissue. ${ }^{2}$ Excessive maternal iodine intake during pregnancy is a well-known mechanism of fetal thyroid disease. High iodine exposure can lead to the development of fetal hypothyroidism and fetal goiter. ${ }^{3}$ Among fetuses with congenital hypothyroidism, only $3 \%$ manifest fetal goiter, with a prevalence of 1 per 40.000 live births. ${ }^{1,4}$ Fetal thyroid enlargement or goiter can be diagnosed based on nomograms of the thyroid circumference related to the gestational age, or of its biparietal diameter. ${ }^{1}$ In the present case report, we describe two cases of three fetuses (one pair of twins, wherein both fetuses were affected, and one singleton pregnancy) with fetal thyroid enlargement and goiter caused by excessive maternal iodine exposure during pregnancy from unprescribed supplements.

\section{Case Report}

The first case is a primiparous 27-year-old pregnant woman who presented with polyhydramnios at the $22^{\text {nd }}$ week of the pregnancy. At the $28^{\text {th }}$ week, a hyperechoic thyroid gland trespassing the $98^{\text {th }}$ centile was observed ( - Fig. 1). Esophageal pouch sign was observed, and the polyhydramnios persisted. During anamnesis, the patient reported the use of vitamin supplements, including iodine, with unknown daily dosage. The patient was informed of the possibility of iatrogenic fetal goiter, and she spontaneously interrupted the intake of vitamins. After 1 week, the patient presented normal thyroid function tests performed 1 week before, and the size of the fetal thyroid gland reduced to $28 \mathrm{~mm} \times 7 \mathrm{~mm}$; however, the polyhydramnios and the pouch sign persisted. At the $31^{\text {st }}$ week, the thyroid gland measured $25 \mathrm{~mm} \times 5 \mathrm{~mm}$, the amniotic fluid was normal, the pouch sign was invisible, and the amniotic fluid was normal even at the $35^{\text {th }}$ week.

The second case is a 32-year-old woman G1P0, presenting with a dichorionic diamniotic pregnancy and an enlarged hyperechogenic mass on the anterior neck of fetus 2 in the 22-week scan (-Figs. 2, 3 and 4). When inquired about the use of iodine supplementation, the patient mentioned the regular use of vitamin supplements with individualized
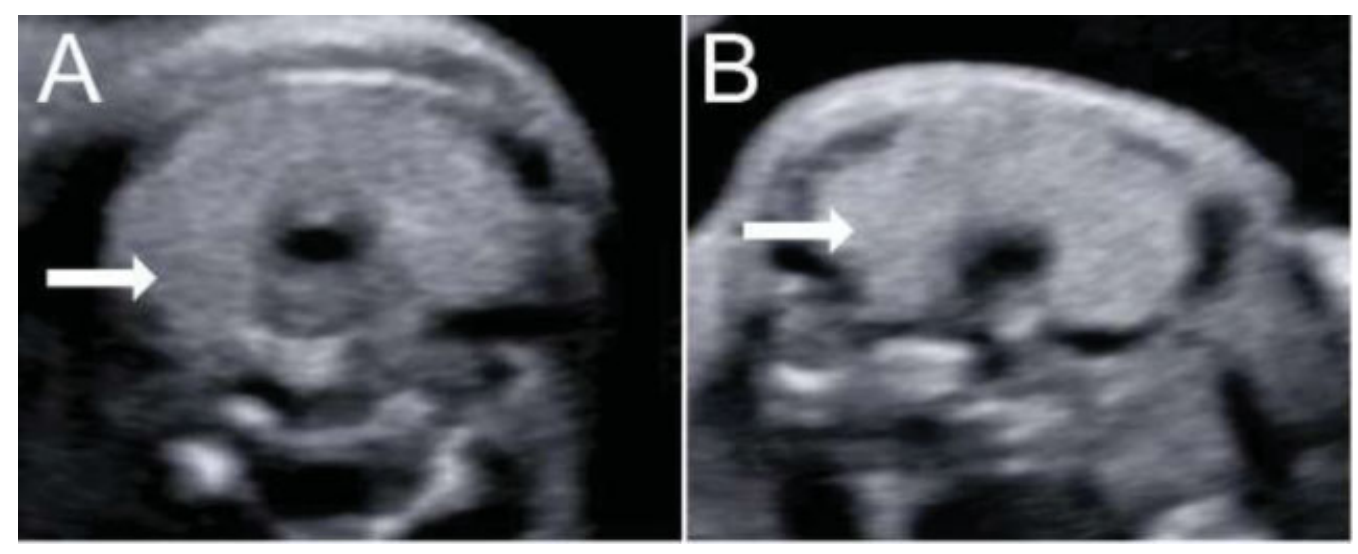

Fig. 1 Two-dimensional ultrasonography of fetal thyroid gland (arrows) at the $28^{\text {th }}(\mathrm{A})$ and at the $31^{\text {st }}$ week (B). The reduction in volume is visible in a few weeks. 


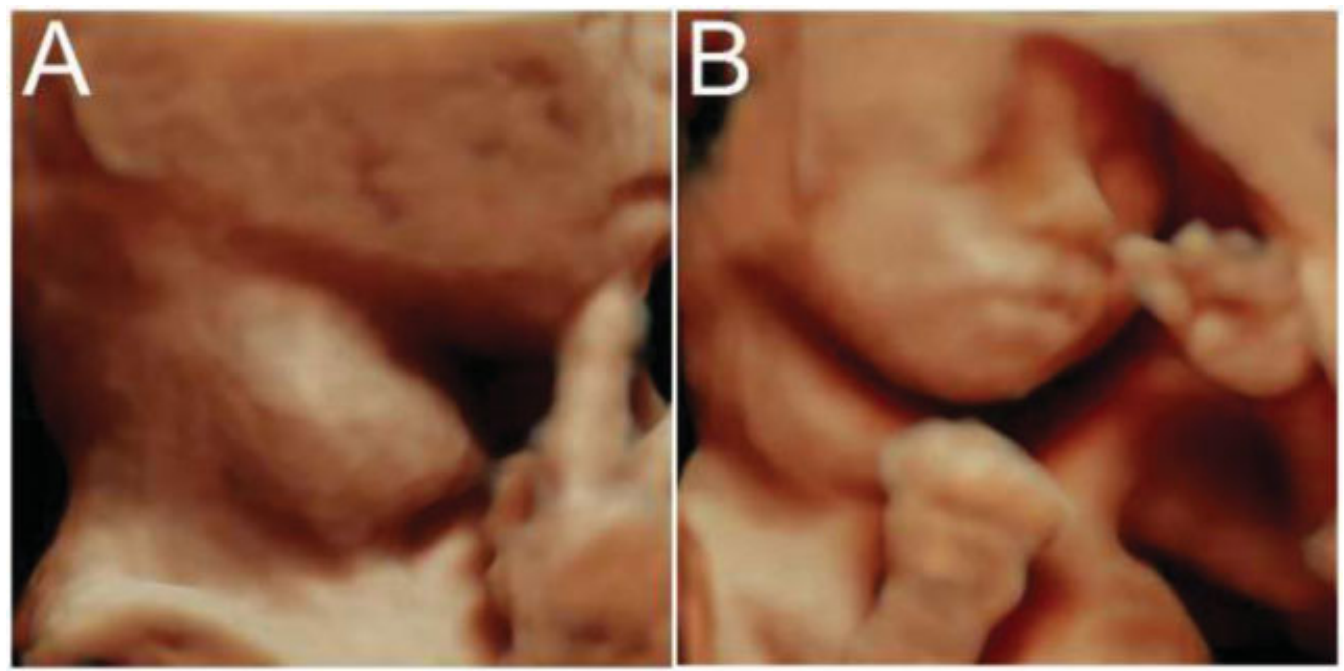

Fig. 2 Three-dimensional ultrasonography in the rendering mode reconstruction of fetus 2 at the $22^{\text {nd }}$ week showing enlarged thyroid gland.

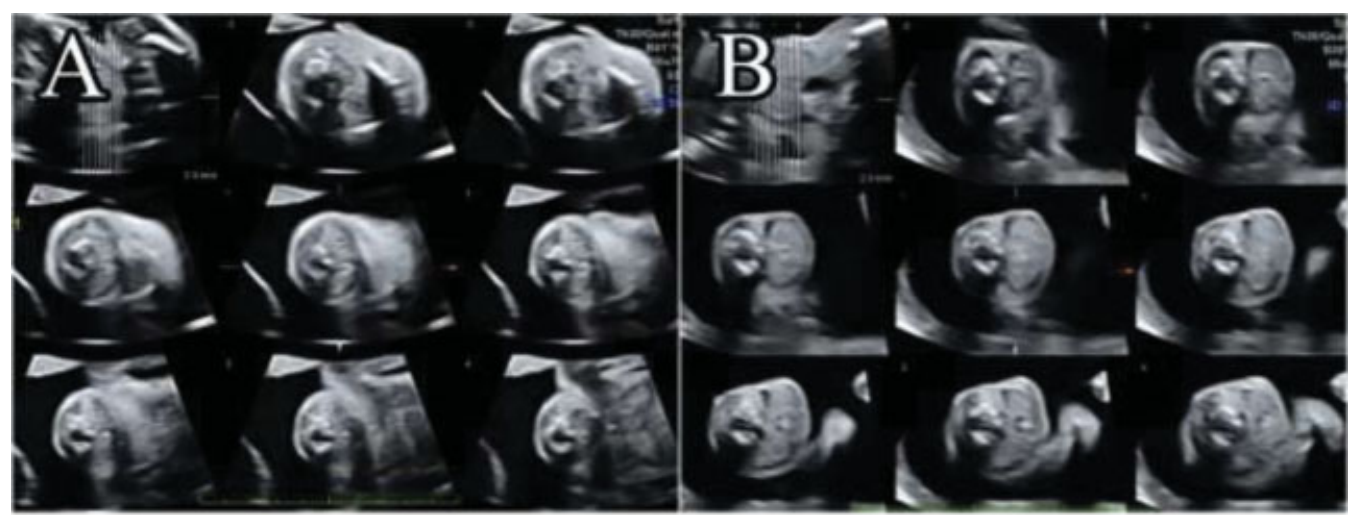

Fig. 3 Three-dimensional ultrasound in the tomographic ultrasound imaging mode of the thyroid gland of fetus 1 (A) and fetus 2 (B) at the $22^{\text {nd }}$ week, showing disproportion and enlargement of the thyroid gland of fetus 2 .
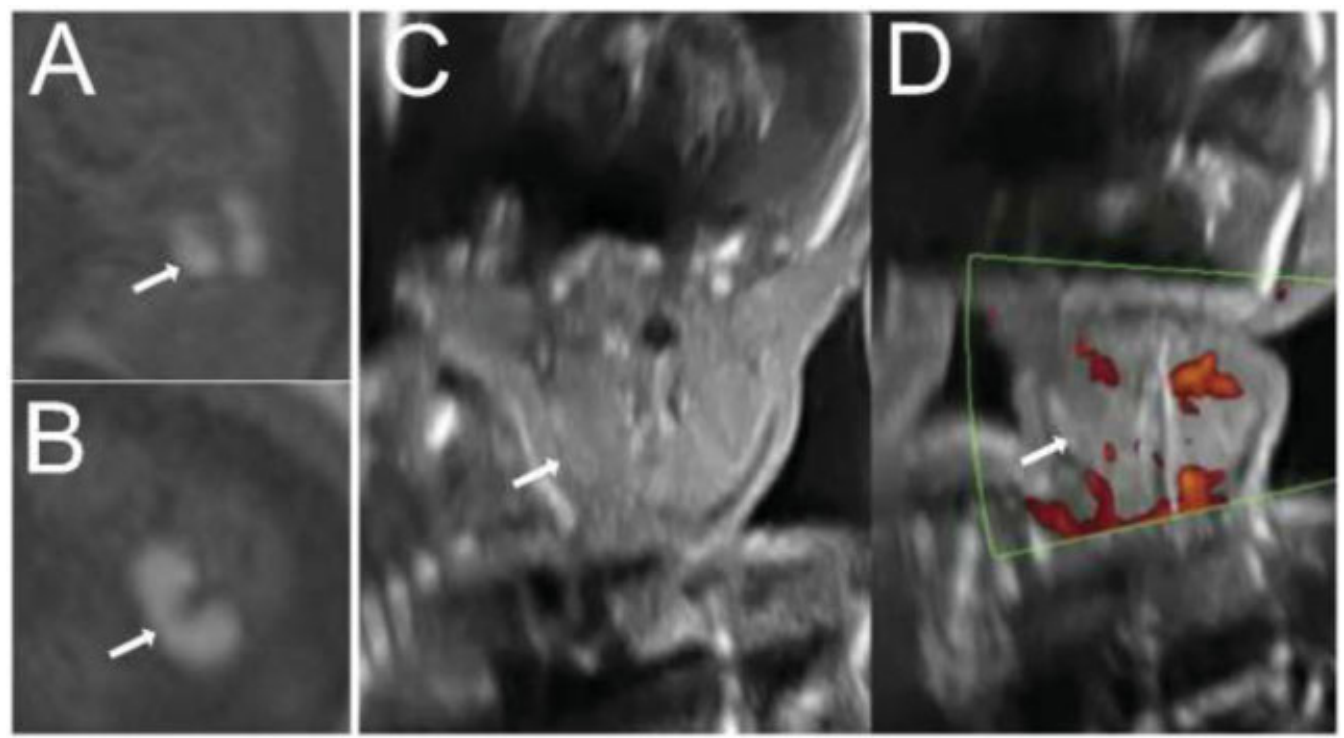

Fig. 4 Fetus 2 at 22 weeks. Magnetic resonance imaging T1-weighted sequences of the neck showing the hyperintense signal of the thyroid gland (A, coronal; and B, axial), ultrasound images of the thyroid gland with and without color Doppler (C and D). 


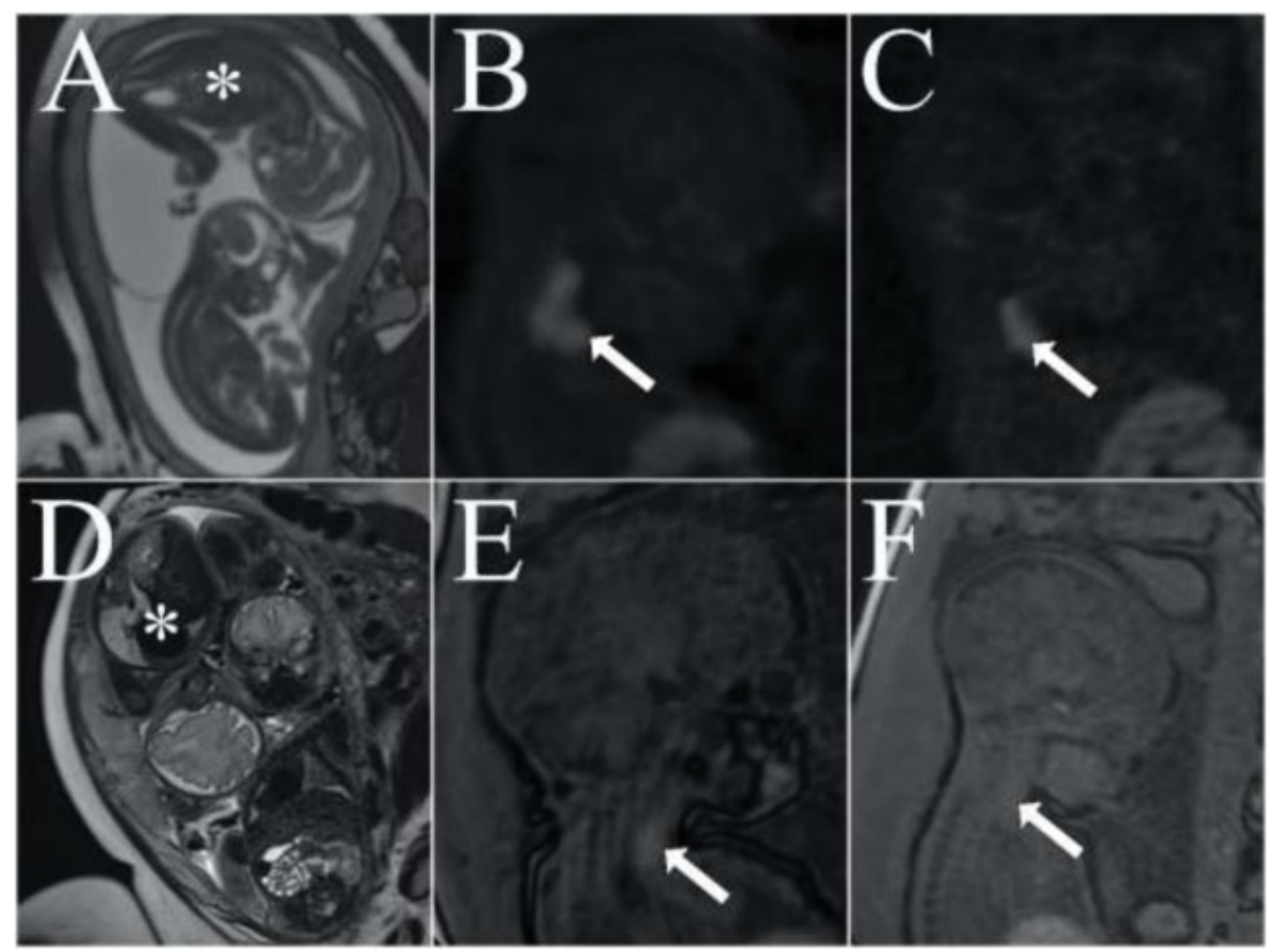

Fig. 5 A, B, and C: Magnetic resonance imaging (MRI) at the $28^{\text {th }}$ week. A: T2-weighted sequence showing fetus 2 (asterisk) in polyhydramnios. B: T1-weighted sequence showing enlarged thyroid gland with hyperintense signal in fetus 2. C: The hyperintense signal is present in fetus 1 , but with the thyroid gland presenting normal dimensions. D, E, and F: MRI performed at the $33^{\text {rd }}$ week. D: the amniotic fluid volume remained normal (fetus 2, asterisk). E and F: Fetuses with thyroid glands presenting normal dimensions and intensity compared with images B and C.

dosages, prescribed by a lay person. In the same week, magnetic resonance imaging (MRI) was performed, which revealed hyperintense thyroid glands in both fetuses on T1-weighted sequence. Polyhydramnios was present, but there were no signs of esophageal compression. The patient was advised to discontinue the supplement intake, to which she promptly agreed. Also, the thyroid function was evaluated, with normal results. Fetal ultrasound examination performed at the $25^{\text {th }}$ week demonstrated a reduction in the dimensions of both thyroid glands, and the MRI demonstrated normal intensity in both thyroid glands on the T1-weighted sequence at the $33^{\text {rd }}$ week (-Fig. 5).

\section{Discussion}

Fetal goiter is an unusual finding in prenatal ultrasound screening. As an essential element required for the synthesis of thyroid hormones, iodine is concentrated in the thyroid gland, and it crosses the placenta via active transport for fetal utilization. However, excessive iodine exposure can cause fetal goiter and thyroid dysfunction. ${ }^{5}$

In the end of the last century, studies reported the effects of subclinical hypothyroidism and neurocognitive development of offspring, thereby increasing the attention toward supplementation and research on the thyroid gland during pregnancy. ${ }^{6,7}$ The World Health Organization (WHO) has recommended the assessment of urinary iodine concentration (UIC) in pregnant and lactating women, a new standard to assess the iodine nutrition status. A UIC level $<150 \mu \mathrm{g} / \mathrm{L}$ is considered as an insufficient iodine status, between 150 and $249 \mu \mathrm{g} / \mathrm{L}$ as adequate, between 250 and $499 \mu \mathrm{g} / \mathrm{L}$ as more than adequate, and $>500 \mu \mathrm{g} / \mathrm{L}$ as excessive. Furthermore, different guidelines recommend an increase in daily iodine intake to $250 \mu \mathrm{g}$ during pregnancy and lactation. ${ }^{8}$ However, iodine supplementation can have other effects on pregnancy outcomes. A study including 9,245 pregnant women in the $1^{\text {st }}$ trimester conducted in an iodine-sufficient region concluded that iodine supplementation in pregnancy must not exceed the UIC value of $250 \mu \mathrm{g} / \mathrm{L}$. Values above this limit significantly increased the risk of developing subclinical hypothyroidism, and a significantly high risk of hypothyroxinemia was observed in pregnant women when the UIC was $>500 \mu \mathrm{g} / \mathrm{L}^{9}$

Excessive iodine intake inhibits thyroid hormone secretion and thyroid biosynthesis in healthy individuals in an acute period. After a prolonged excessive iodine intake, the thyroid function returns to normal levels. This phenomenon is known as escape from Wolff-Chaikoff effect and protects against the overproduction of thyroid hormones after iodine overexposure. However, some individuals, including fetuses, do not escape these effects and develop acquired isolated hypothyroxinemia. The immature fetal and neonatal thyroid glands are unable to reduce the intracellular iodine transportation; although excessive iodine is available, hypothyroidism persists. This hypothyroidism can resolve spontaneously after the cessation of excessive iodine intake. $^{10}$ 
The effects of fetal thyroid disease have been well described. Normal neurodevelopment requires an adequate amount of maternal thyroid hormones during the $1^{\text {st }}$ half and the $2^{\text {nd }}$ half of pregnancy by the maternal and fetal thyroids. Increase in this hormonal production demands the doubling of pregestational requirements of iodine intake. During the $1^{\text {st }}$ half of the pregnancy, human chorionic hormone acts like a thyroid stimulating hormone (TSH). Its molecular activity is proportionally very low compared with that of TSH; however, its concentrations during the $1^{\text {st }}$ trimester are sufficient to inhibit the pituitary secretion of TSH. At between 18 and 22 weeks of gestation, the pituitary-portal vascular system is fully developed, and the fetus is able to produce thyroid hormones. ${ }^{11}$ The concentration of thyroid hormones and the activity of deiodinases have been investigated in different areas of the fetal brain. ${ }^{12}$ These hormones have a particular action in the neurogenesis and in the migration of radial neurons in the developing cortex and cerebellum, changing and adding complexity in their cytoarchitecture even during the neonatal life. ${ }^{11}$

With several etiologies, including congenital dyshormonogenesis, excess or deficiency of iodine, and others, fetal goiter is a less frequent consequence of fetal hypothyroidism, but increases fetal and neonatal morbidity due to congenital thyroid dysfunctions. The direct impact of thyroid masses can lead to obstruction of the airways and of the esophagus, increasing the risk of preterm birth from polyhydramnios and requiring a multidisciplinary team to secure the neonatal airway through the ex-utero intrapartum treatment procedure. The compressive effect on the airway and on the esophagus is a predictable complication, wherein MRI has an important role in the assessment of soft tissues and to characterize the permeability of the airway. Magnetic resonance imaging has also been used for virtual reconstruction of the airways and delivery planning in cervical masses. ${ }^{13}$

In the cases presented here, identification of the possible cause of fetal goiter and cessation of supplemental ingestion led to conservative management with posterior regression of the goiter in both singleton and twin pregnancies. A previous study also described the regression of fetal hypothyroidism in twin pregnancy, or goiter, caused by excessive iodine intake. $^{14}$

Intra-amniotic levothyroxine injections have been proposed for the treatment of fetal goiter and hypothyroidism based on evidence suggesting that treatment delay increases the risk for impaired development in the infant. ${ }^{15}$ Intra-amniotic therapy presents good results in progressive and dysfunctional goiters, decreasing the risk of perinatal complications. However, evidence indicating the benefits on neurodevelopment outcomes is scarce and controversial. The evident reduction in thyroid volume after the cessation of iodine supplements in our cases associated with the risk of invasive procedures guided the decision to follow-up the pregnancy conservatively. Unfortunately, the effects of the thyroid function on the long-term outcomes of the neonates are unknown, as well as the results of the thyroid function tests after delivery.

\section{Conclusion}

In conclusion, we reported a case of a twin pregnancy affected by fetal goiter in both fetuses, which was induced by an excessive intake of iodine supplementation during the pregnancy, with successful regression after supplement suspension. Excessive iodine intake should be investigated as a possible cause of fetal goiter.

Conflict of Interests

The authors have no conflict of interests to declare.

\section{References}

1 Ranzini AC, Ananth CV, Smulian JC, Kung M, Limbachia A, Vintzileos AM. Ultrasonography of the fetal thyroid: nomograms based on biparietal diameter and gestational age. J Ultrasound Med. 2001;20(06):613-617. Doi: 10.7863/jum.2001.20.6.613

2 Grosse SD, Van Vliet G. Prevention of intellectual disability through screening for congenital hypothyroidism: how much and at what level? Arch Dis Child. 2011;96(04):374-379. Doi: 10.1136/adc.2010.190280

3 Pearce EN, Lazarus JH, Moreno-Reyes R, Zimmermann MB. Consequences of iodine deficiency and excess in pregnant women: an overview of current knowns and unknowns. Am J Clin Nutr. 2016; 104(Suppl 3):918S-923S. Doi: 10.3945/ajcn.115.110429

4 Mastrolia SA, Mandola A, Mazor M, Hershkovitz R, Mesner O, Beer-Weisel R, et al. Antenatal diagnosis and treatment of hypothyroid fetal goiter in an euthyroid mother: a case report and review of literature. J Matern Fetal Neonatal Med. 2015;28(18): 2214-2220. Doi: 10.3109/14767058.2014.983062

5 Glinoer D. Pregnancy and iodine. Thyroid. 2001;11(05):471-481. Doi: 10.1089/105072501300176426

6 Haddow JE, Palomaki GE, Allan WC, Williams JR, Knight GJ, O'Heir $\mathrm{CE}$, et al. Maternal thyroid deficiency during pregnancy and subsequent neuropsychological development of the child. N Engl J Med. 1999;341(08):549-555. Doi: 10.1056/NEJM199908193410801

7 Teng W, Shan Z, Patil-Sisodia K, Cooper DS. Hypothyroidism in pregnancy. Lancet Diabetes Endocrinol. 2013;1(03):228-237. Doi: 10.1016/S2213-8587(13)70109-8

8 Stagnaro-Green A, Abalovich M, Alexander E, Azizi F, Mestman J, Negro R, et al; American Thyroid Association Taskforce on Thyroid Disease During Pregnancy and Postpartum. Guidelines of the American Thyroid Association for the diagnosis and management of thyroid disease during pregnancy and postpartum. Thyroid. 2011;21(10):1081-1125. Doi: 10.1089/thy.2011.0087

9 Shi X, Han C, Li C, Mao J, Wang W, Xie X, et al. Optimal and safe upper limits of iodine intake for early pregnancy in iodinesufficient regions: a cross-sectional study of 7190 pregnant women in China. J Clin Endocrinol Metab. 2015;100(04):1630-1638. Doi: 10.1210/jc.2014-3704

10 Overcash RT, Marc-Aurele KL, Hull AD, Ramos GA. Maternal iodine exposure: a case of fetal goiter and neonatal hearing loss. Pediatrics. 2016;137(04):e20153722. Doi: 10.1542/peds.2015-3722

11 de Escobar GM, Ares S, Berbel P, Obregón MJ, del Rey FE. The changing role of maternal thyroid hormone in fetal brain development. Semin Perinatol. 2008;32(06):380-386. Doi: 10.1053/j. semperi.2008.09.002

12 Kester MH, Martinez de Mena R, Obregon MJ, Marinkovic D, Howatson A, Visser TJ, et al. Iodothyronine levels in the human developing brain: major regulatory roles of iodothyronine deiodinases in different areas. J Clin Endocrinol Metab. 2004;89(07): 3117-3128. Doi: 10.1210/jc.2003-031832

13 Werner H, Lopes dos Santos JR, Fontes R, Belmonte S, Daltro P, Gasparetto E, et al. Virtual bronchoscopy for evaluating cervical 
322 Excessive Prenatal Supplementation of lodine and Fetal Goiter Castro et al.

tumors of the fetus. Ultrasound Obstet Gynecol. 2013;41(01): 90-94. Doi: 10.1002/uog.11162

14 Thomas JdeV, Collett-Solberg PF. Perinatal goiter with increased iodine uptake and hypothyroidism due to excess maternal iodine ingestion. Horm Res. 2009;72(06):344-347. Doi: 10.1159/000249162
15 Derksen-Lubsen G, Verkerk PH. Neuropsychologic development in early treated congenital hypothyroidism: analysis of literature data. Pediatr Res. 1996;39(03):561-566. Doi: 10.1203/00006450199603000-00028 